Trivent Publishing

(C) The Authors, 2016

Available online at http://trivent-publishing.eu/

Series: Philosophy, Communication, Media Sciences

Volume: Communication Today: An Overview from Online Journalism to Applied Philosophy

\title{
Multilingual Indexing in an Intercultural Context
}

\author{
Maria Micle, ${ }^{1}$ Agneta Lovasz ${ }^{2}$ \\ ${ }^{1}$ West University of Timisoara. Faculty of Political Science, Philosophy, Communication Science, \\ Romania, maria.micle@e-uvt.ro \\ ${ }^{2}$ Politehnica University Timişoara, Library Depatment, Romania, agneta.lovasz@gmail.com
}

\begin{abstract}
Thanks to the impressive technological progress in communication, library users in the academic environment (teachers, researchers and students) enjoy growing autonomy and flexibility in study, research and documentation, facilitated by access to various information resources and specific search tools, especially in the virtual environment.

Autonomy in information retrieval is one of the main goals of university libraries done through developing services and tools. The indexing process in libraries consists of the representation of a document's content in a summarized form in order to ease information retrieval; the content analysis focuses, among others, on avoiding communication barriers between the public and the sources of information. The process developed from linear indexing (with a hierarchical structure) into coordinated indexing through descriptors or keywords. Inter- and trans-disciplinarity can be manifested in this form, although in this form it is entirely dependent on computing. In the intercultural context of libraries today, where language interference is part of everyday routine, the accessibility to collections depends increasingly on multilingual indexing. This however is not limited to the simple translation of the terms in the catalogue to the languages most used in the library, but also requires the creation of specialized multilingual thesauri.

This work illustrates these areas of multilingual indexing proposing some examples of controlled vocabulary, extracted from a micro-thesaurus of the technical field of Mechanisms with descriptors in English, Romanian, German, and French.
\end{abstract}

\section{Keywords}

Academic library; intercultural context; multilingual indexing; informational content analysis.

This is an Open Access article distributed in accordance with the Creative Commons Attribution Non Commercial (CC-BYNC-ND 4.0) license, which permits others to copy or share the article, provided original work is properly cited and that this is not done for commercial purposes. Users may not remix, transform, or build upon the material and may not distribute the modified material (http://creativecommons.org/licenses/by-nc/4.0/)

DOI: $10.22618 /$ TP.PCMS.20164.349009 


\section{The intercultural context of universities and libraries}

Within the context of globalization, the social environment of libraries witnesses an increasing amount of situations in which people interact in an inter-cultural way (for instance traditional local groups and the migration phenomenon which is ever-present nowadays). Romanian universities (including their libraries) are constantly developing internationalization strategies which aim for two main goals (among others): on the one hand, intensifying academic exchanges; and on the other hand, the rise of the quantity and quality of academic mobility for both research and teaching within EU and worldwide institutions (the Erasmus+ programme or the EEA mobility programmes are designed specifically for these scopes). Both the West University of Timișoara ${ }^{1}$ and the Politehnica University Timișoara ${ }^{2}$ benefit from Erasmus partnerships - mainly with similar European institutions. Their libraries have to integrate services for non-Romanian speakers as the foreign student and professor inflow is growing each year - hence, the necessity of multicultural-principled libraries. ${ }^{3}$

\section{Educational perspectives of the culture of information. The process of creating autonomous documentation}

In the academic environment, the process of teaching/learning is departing from the previous overwhelmingly-tutorial model of the student-professor relationship. The efficiency of the pedagogical practices of the 1980s is seriously questioned as students now have a greater autonomy in crafting their own professional trajectory. The users of academic libraries (students, instructors, researchers) have a greater flexibility and autonomy when studying and doing research, especially as they are supported by new communication and information technologies which allow access to various informational resources (most notably electronic ones). The three main components of a library remained the same throughout centuries (trio significat: Locum, Armarium, Libros ${ }^{4}$ ), but they tend to take a step back in the consciousness of contemporary society; the library, as a physical space to access information starts suffering from a lack-of-localization process as information now tends to be more and more accessible in the virtual space.

The independence of library users in finding scientific information is one of the purposes of university libraries. Libraries aim for this by developing new services and instruments to access information, to analyze, and to select informational content; however, this development must be carefully prepared, beginning with teaching the public and, most importantly, the library personnel some basic digital competences. The complexity of library activities needs its personnel to develop professional competences; unfortunately, the needed competences are inadequate for the Romanian informational space, thus a large discrepancy may be created between what is expected from a librarian and what a librarian can offer. ${ }^{5}$

\footnotetext{
${ }^{1}$ West University of Timisoara. Collaboration agreements with international partners. http://ri.uvt.ro/afilieri-laasociatii-internationale_en/?lang=en (accessed: 15.04.2016).

2 Politehnica University Timisoara. Strategic Plan for the Internationalisation of Education 2015-2010. http://www.upt.ro/img/file/Proceduri/Strategy_for_internationalisation_UPT_2015_2020.pdf $\quad$ (accessed: 4.02.2016).

3 IFLA. Manifestului Bibliotecilor Multiculturale. http://www.ifla.org/files/assets/library-services-tomulticultural-populations/publications/multicultural_library manifesto-ro.pdf (accessed: 15.04.2016).

${ }^{4}$ Justus Lipsius. "De bibliothecis syntagma" in Opera omnia, vol. 3 (Vesaliae, 1675), 1122; Brook Sheldon. Manager sau lider. Noi atribuții ale specialiștilor în știința informării [Manager or leader. New attributions of scientists in the science of information]. Apud: Tendințe contemporane in biblioteconomie și știința informării, ed. Hermina Anghelescu (Iaşi: Editura Shakti, 1996), 4.

${ }^{5}$ Elena Tîrziman and Maria Micle, "Adapting Librarians' Professional Competences to Current Requirements through Initial Education and Lifelong Education.," in European Journal of Social Sciences Education and Research. 6 (2016): 164. http://ejser.euser.org/ (accessed: 4.05.2016).
} 


\section{Indexing - an instrument for the independent search for information}

The rising "industrialization" of information needs complex instruments for its organization (and for efficiently finding information), thus indexing and abstracting is currently adapting its techniques in order to correspond to this phenomenon. The process of indexing consists in representing the content of a document in a summarized form, using indexing terms in order to ease the finding and consultation process.

Coordinated indexing is a method for documentary analysis in which the content of documents is characterized with the help of specialized terms (words or syntagmas) and/or symbols which represent unique concepts and belong to a documentary language, while the information in the documents is found by recombining these terms. ${ }^{6}$

Within 20 years, linear indexing (done internationally by well-known classifications such as CZU and Dewey) was replaced by coordinated indexing through the use of descriptors and keywords. The interdisciplinarity of the informational content can easily be manifested in this form, but is dependent on technology and the virtual environment, with all its constraints owed to the process of automated indexing. Although the main principles and theories of indexing have only changed a little compared to the 1990s, the need of indexing of electronic resources was added. ${ }^{7}$

Most online library systems worldwide utilize some type of controlled and, in many cases, multiple vocabularies. From a librarian's point of view, keyword searching on the Internet has its limitations. Yet online catalogs exist in the Internet environment along with other remotely accessible databases which may utilize their own controlled vocabularies."

Abstracting (as a complementary component of indexing in characterizing an informational content) receives more and more interest as a modern technique; the difference between abstracting and indexing is that indexing allows the combination of terms in order to find information in the most efficient way, while an abstract is a narrative description of the content. ${ }^{9}$

\section{Multilingual indexing - techniques and instruments}

In the intercultural context of libraries, linguistic interferences are part of the everyday, both on a public level and on the level of collections. Multilingual indexing in bibliographical databases tends to be included in an increasing number of academic and national libraries. This practice is one of the methods of decreasing the "curse of Babel," 10 the communicational obstructions owed to the linguistic diversity of the information and its users - at least in the electronic catalogues of libraries.

\footnotetext{
${ }^{6}$ Institutul Național de Informare și Documentare [The National Institute for Information and Documentation INID]. Metode de indexare în activitatea de informare şi documentare [Indexing methods in the activity of information and documentation] (Bucharest, 1989), 70.

${ }^{7}$ E.W. Lancaster, Indexing and Abstracting in Theory and Practice (London: Library Association Publishing, 1998), VII.

${ }^{8}$ Association for Library Collections and Technical Services Subject Analysis Committee. Report of the Subcommittee on Semantic Interoperability to the ALCTS Subject. June 2006. http://www.ala.org/alcts/sites/ala.org.alcts/files/content/mgrps/camms/cmtes/sac/inact/semantic/sacsem_rpt.pdf (accessed: 22.04.2016), 6.

${ }^{9}$ E. W. Lancaster, E.W. Indexing and Abstracting, 5-7.

${ }^{10}$ Alberto Manguel, Un cititor în pădurea din oglindă [A reader in the forest in the mirror] (Bucharest: Nemira, 2016), 322.
} 


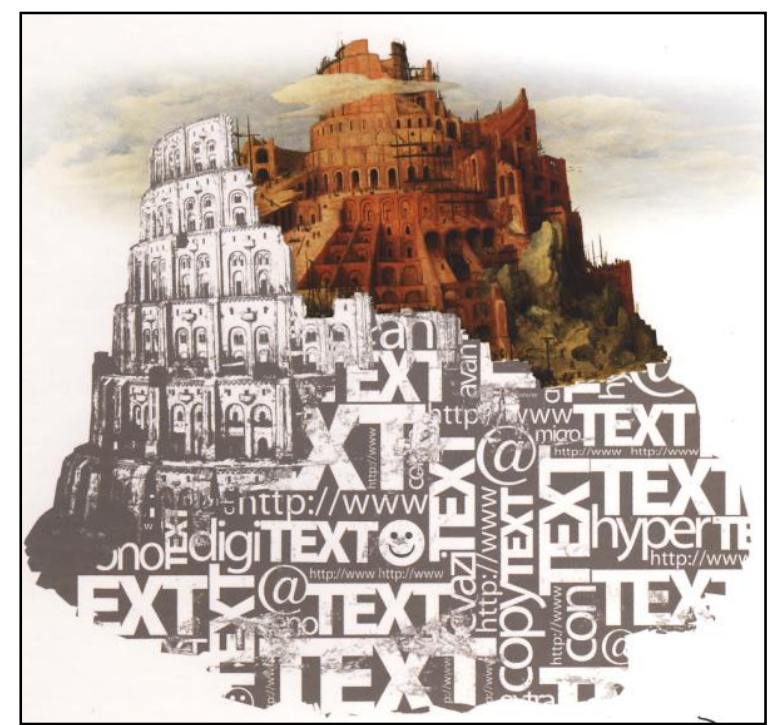

Fig. 1: Detail from the cover of the book titled Dincolo de text: hypertextul şi comunicarea online, by Elena Ungureanu ${ }^{11}$

In Romania, multilingual indexing in library bibliographical databases is at its beginning; there are only a few isolated initiatives such as those in the Central Library of "Lucian Blaga" University from Cluj-Napoca, the Central Library "Eugen Todoran" from the West University of Timișoara, the Library of the Politehnica University of Timișoara.

\section{Multilingual descriptors: the example of the indexing term "cogwheel" from the micro-thesaurus in the technical field of "mechanisms"}

In indexing language, descriptors (formed and especially accepted in unique forms) can be collected in thesauri, meaning in standardized and descriptive thematic lists arranged alphabetically (also known as lists of authorities) in which one can search in natural language. ${ }^{12}$

A thesaurus is, in fact, a controlled and flexible vocabulary of terms linked among each other through semantic and generic relations which are applied in a specific field of knowledge. Practically, the terms named in a thesaurus (either simple or compound) are organized in a conceptual manner which highlights their grouping based on semantic compatibility and indicate the relationship between the terms. ${ }^{13}$

Generally, in a thesaurus, the presentation of a descriptor contains the following elements: the descriptor itself, ${ }^{14}$ the explanation, ${ }^{15}$ the general category of the term, ${ }^{16}$ the generic term, ${ }^{17}$ the

\footnotetext{
${ }^{11}$ Source: the cover of the book by Elena Ungureanu. Dincolo de text: hypertextul şi comunicarea online [Beyond text: hypertext and online communication] (Chișinău: Arc, 2014). Accesible online at: Blog de biblioteconomie și știința informării, https://clubbib2.wordpress.com/articole-traduceri/ (accessed: 12.03.2016).

${ }^{12}$ Geneviève Lallich-Boidin, Dominique Maret. Recherche d'information et traitement de la langue (Lyon: Presses de l'ENSSIB, 2005), 249.

${ }^{13}$ INID. Metode de indexare in activitatea de informare și documentare, 82.

${ }^{14}$ The simple or compound indexing term from the given field, presented on a morphological level with its inflected characteristics.

${ }^{15}$ The definition of the term in the indexing process, on a semantic level, in order to facilitate its correct usage.

${ }^{16}$ The most general term. In the examples found in this paper, the VG is the field of mechanism sciences (mechanisms).

${ }^{17}$ The most general term of the sub-field, meaning the hierarchically-inferior term. In the given examples from the field of mechanisms, some of the generic terms may be the following: structure, kinematics, kinetostatics, dynamics, etc.
} 
associate term,${ }^{18}$ the non-descriptive term $;{ }^{19}$ the presentation of the descriptor is meant to highlight the semantic, associative and hierarchical-logical relationship between the terms. Moreover, for a multilingual thesaurus, the descriptors in the desired foreign languages are also added in the thesaurus.

This article exemplifies the semantic sphere of the descriptor "cogwheel," which belongs to the scientific terminology of the technical field of "mechanisms." The term is presented as an indexing term in the architecture of the multilingual micro-thesaurus (Romanian-English-German-French) titled Multilingual Illustrated $\mu$-thesaurus in Mechanisms Science, also used as case study by Agneta Lovasz in her doctoral dissertation. ${ }^{20}$ The notions defined as descriptors are complemented by illustrative images. ${ }^{21}$ This thesaurus contains 440 descriptors in four languages: Romanian, English, German, and French. It was conceived in order to support the usage of an online catalogue by users, but it also aims librarians as an instrument for indexing. The thesaurus has a logical structure on several levels - from particular to general, the last level referring to the general category of the term.

Below is the graphic representation of the descriptor "cogwheel," as an instrument for user questioning:

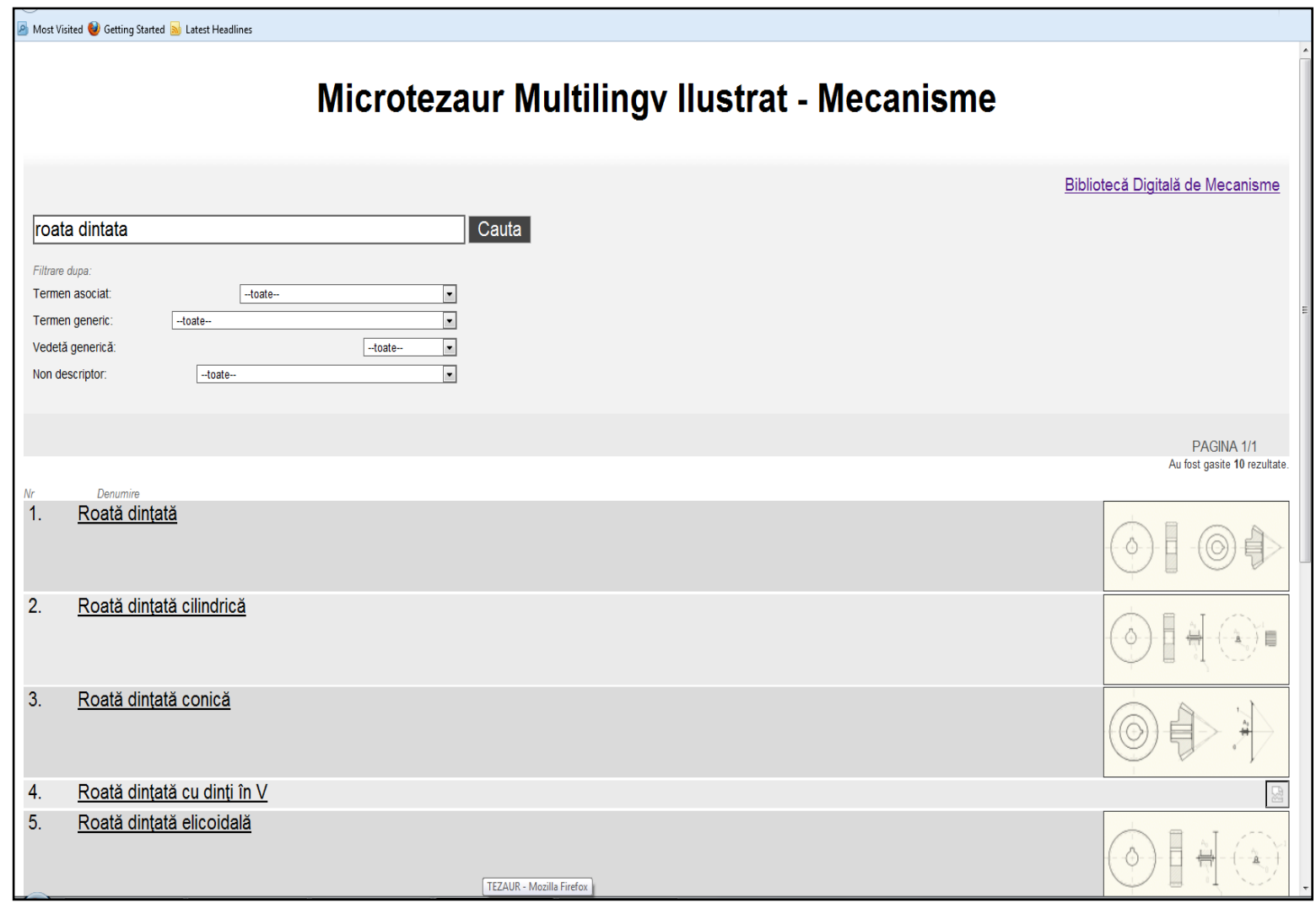

Fig. 2. Extract from Multilingual Illustrated $\mu$-thesaurus in Mechanisms Science

Searching in the thesaurus for "cogwheel," the following results are displayed: cylindrical gear, conical gear, helical gear, V-shaped gear, planar gear.

In the followings, we will present the descriptor "cogwheel," as in the indexing language for librarians.

\footnotetext{
${ }^{18}$ The term associated to the indexing term, on a conceptual level, depending on the sub-field it belongs to.

19 The synonym of the indexing term (if it exists).

${ }^{20}$ Agneta-Elisabeta Lovasz. Dezvoltarea unei biblioteci digitale de mecanisme [The development of a digital library of mechanisms] (Timișoara: Editura Politehnica, 2011), 318.

${ }^{21}$ Lovasz, E.-C., Perju, D., Corves, B., Brix, T., Modler, K.-H., Maniu, I., Gruescu, C.M., Lovasz, A., Ciupe, V. "Multilingual Illustrated $\mu$-thesaurus in Mechanisms Science," in The $1^{\text {st }}$ Workshop on Mechanisms, Transmissions and Applications, Timişoara Romania, 2011.
} 


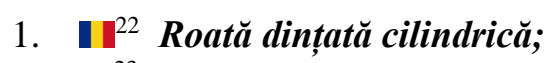

幽 23 Cylindrical gear;

24 Stirnzahnrad; Stirnrad;

I $^{25}$ Roue d'engrenage cylindrique; Roue dentée cylindrique;

The explanation: "cogwheel with cogs displayed on a cylindrical surface"

The general category of the term: Mechanisms

The generic term: Structure

The associate term: Cogwheel

The image of the term:

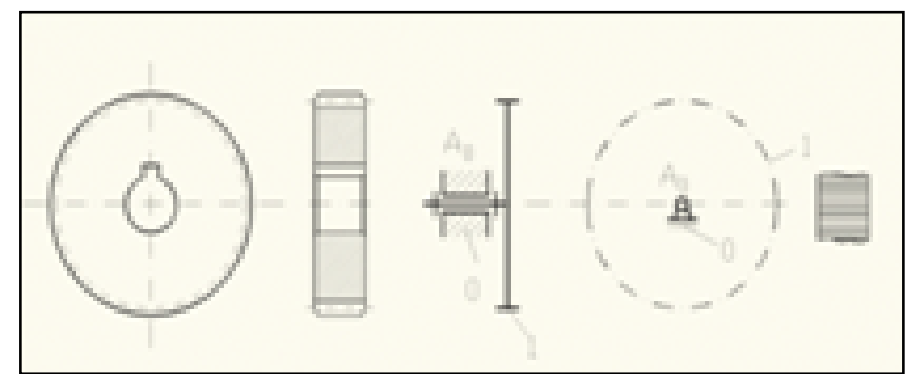

Fig. 3: Cylindrical gear

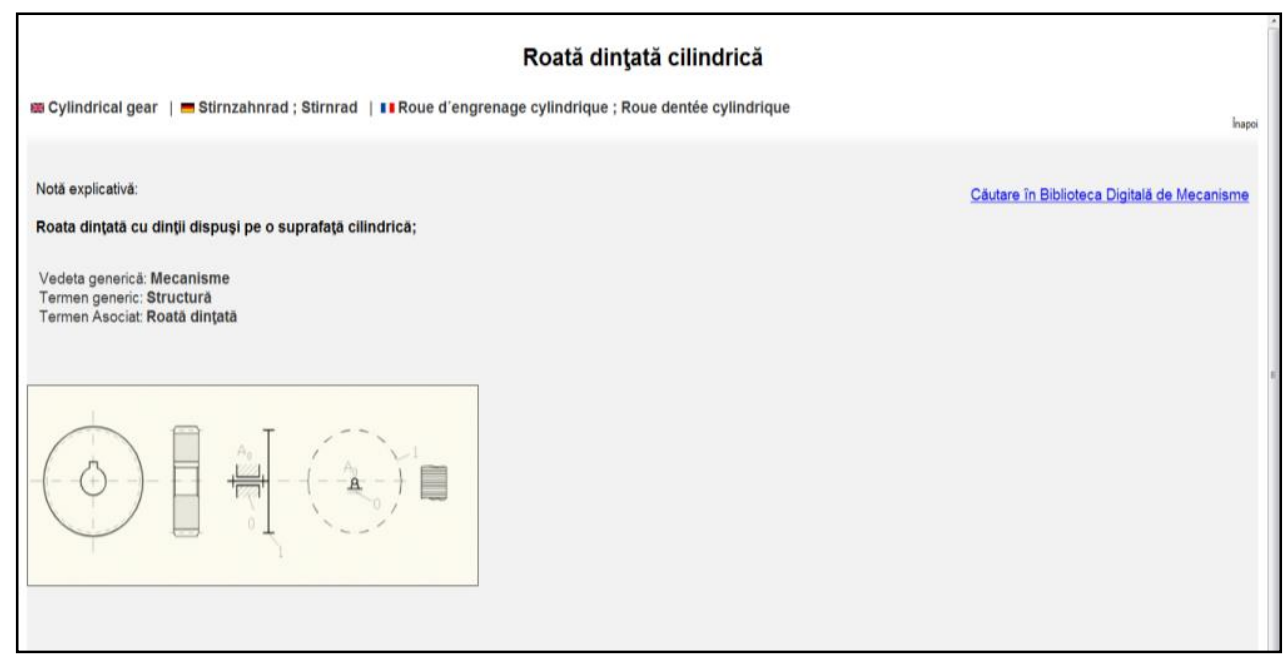

Fig. 4: Extract from the micro-thesaurus

${ }^{22}$ The indexing term in Romanian.

${ }^{23}$ The indexing term in English.

${ }^{24}$ The indexing term in German.

${ }^{25}$ The indexing term in French. 


\section{II Roată dințată conică;}

蹸 Conical gear; Bevel gear;

Kegelzahnrad; Kegelrad;

II Roue dentée conique; Engrenage conique;

The explanation: "cogwheel with cogs displayed on a conical surface"

The general category of the term: Mechanisms

The generic term: Structure

The associate term: Cogwheel

The image of the term:

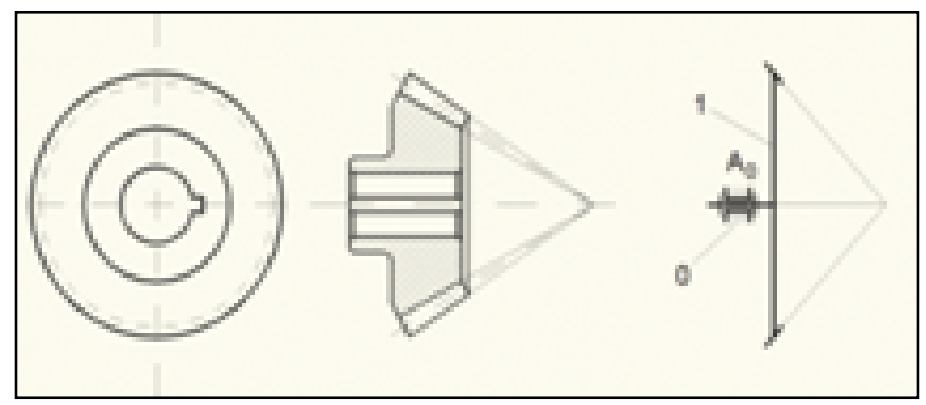

Fig. 5: Conical gear

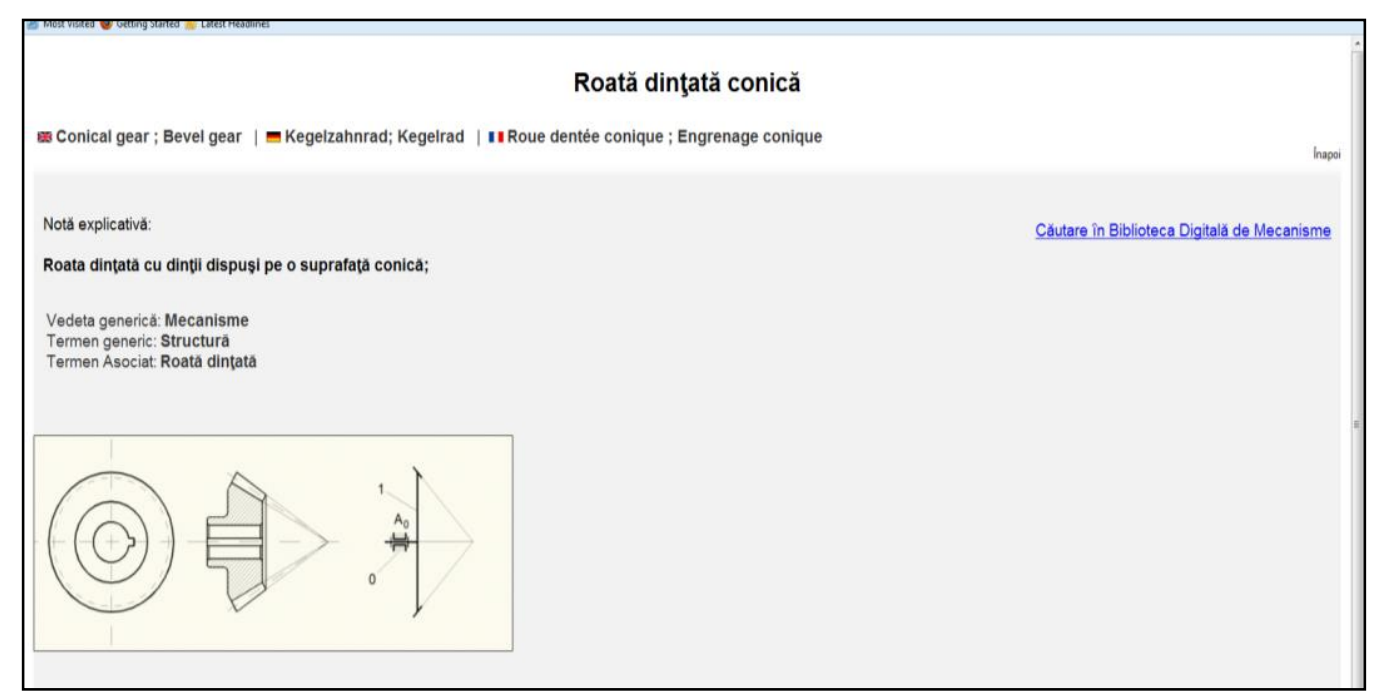

Fig. 6: Extract from the micro-thesaurus

\section{II Roată dințată solară}

米 Sun gear; Sun wheel;

Sonnenrad; Sonnenzahnrad; Mittelzahnrad;

I Roue solaire;Pignon solaire

The explanation: "cogwheel with a fixed rotation axis, which gears with a satellite cogwheel"

The general category of the term: Mechanisms

The generic term: Structure

The associate term: Cogwheel

Non-descriptive term: Central gear 
The image of the term:

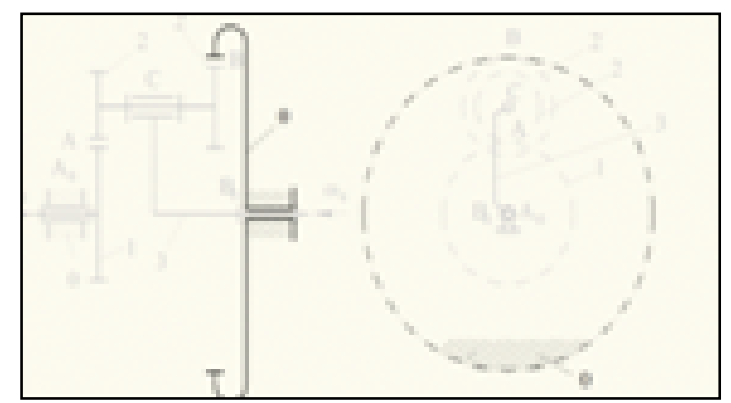

Fig. 7: Sun gear

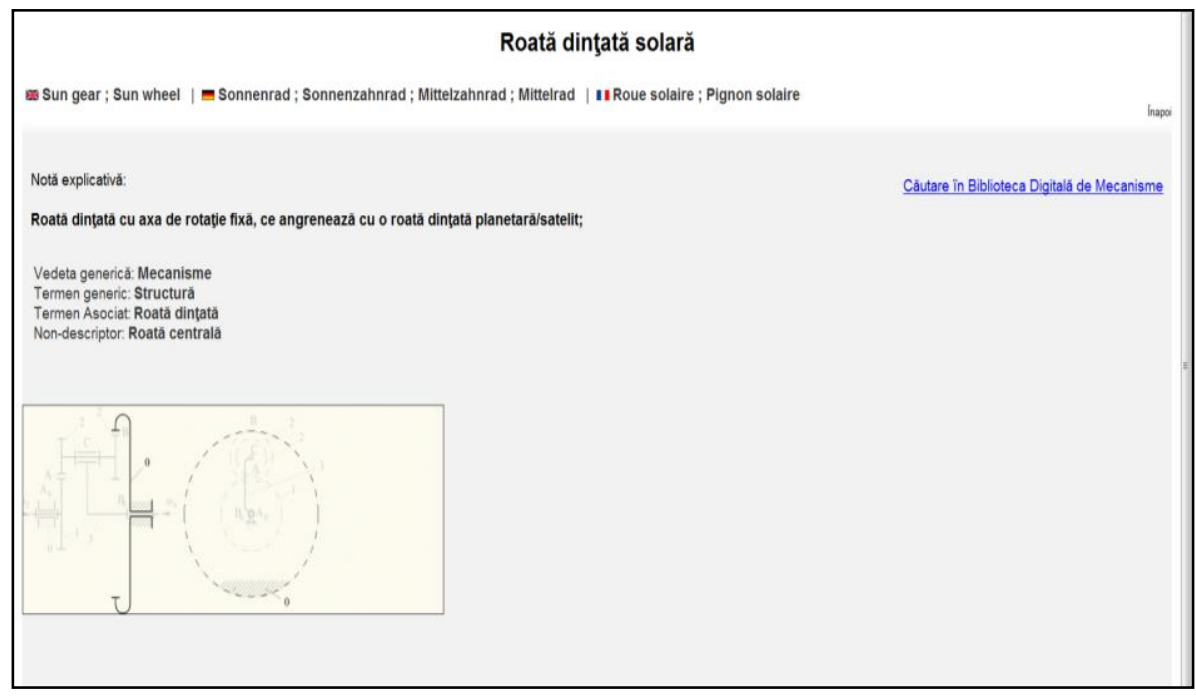

Fig. 8: Extract from the micro-thesaurus

\section{II Roată dințată elicoidală}

米 Helical gear; Helicoidal gear;

Schneckenrad; Schraubenzahnrad; Spiralrad;

II Roue dentée helicoidale; Roue d'engrenage helicoidale

The explanation: "cogwheel with cogs displayed on a helix on a cylindrical surface" The general category of the term: Mechanisms

The generic term: Structure

The associate term: Cogwheel

The image of the term:

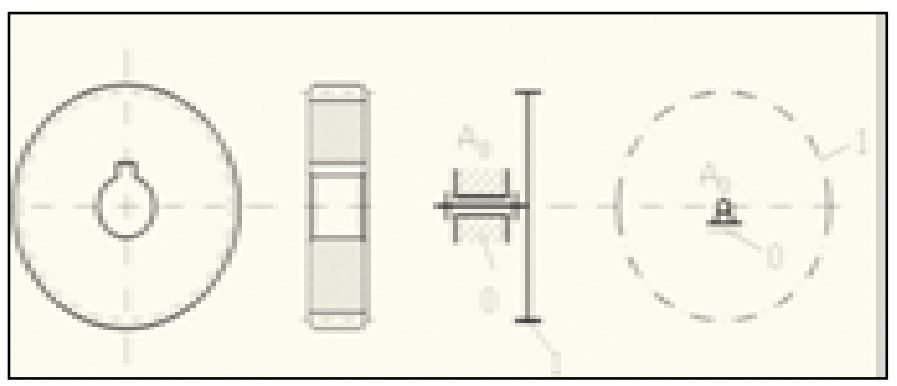

Fig. 9: Helical gear 


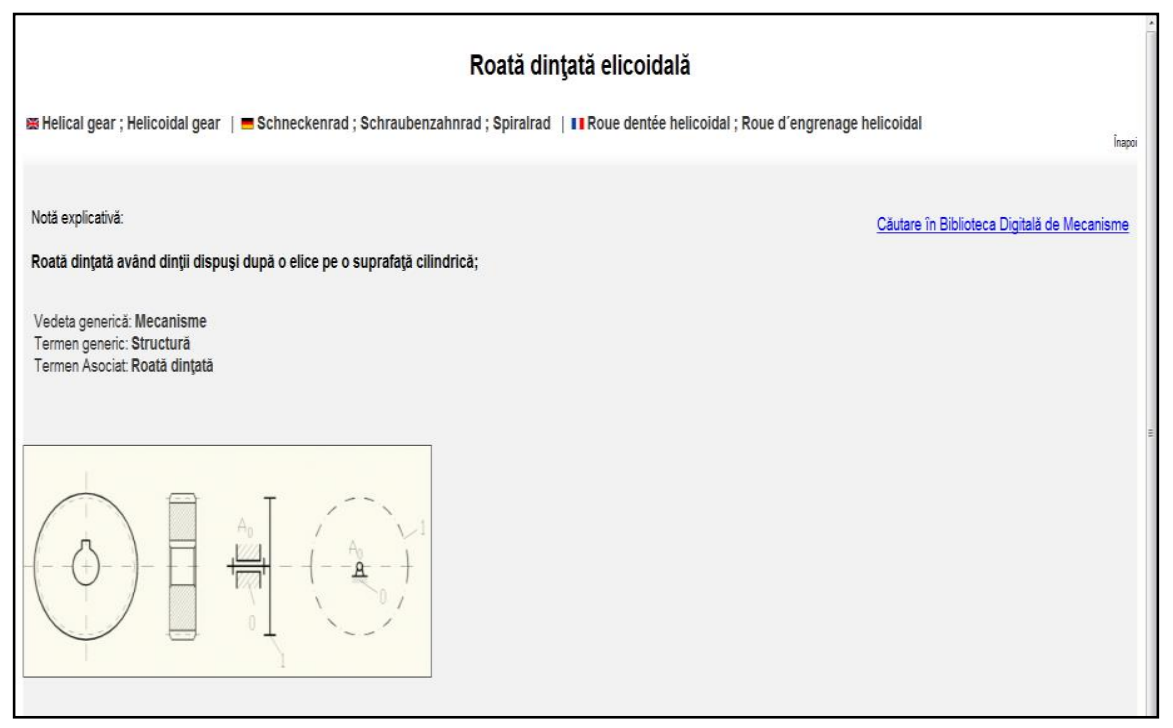

Fig. 10: Extract from the micro-thesaurus

\section{I Roată dințată plană}

类 Planar gear;

Ebene Zahnrad; Plankegelrad;

II Roue dentée plane;

The explanation: „,roată dinţată având dinții dispuși pe o suprafață plană perpendiculară pe axa de rotație sau secțiunea printr-o roată dințată cilindrică perpendiculară pe axa sa".

The general category of the term: Mechanisms

The generic term: Structure

The associate term: Cogwheel

The image of the term:

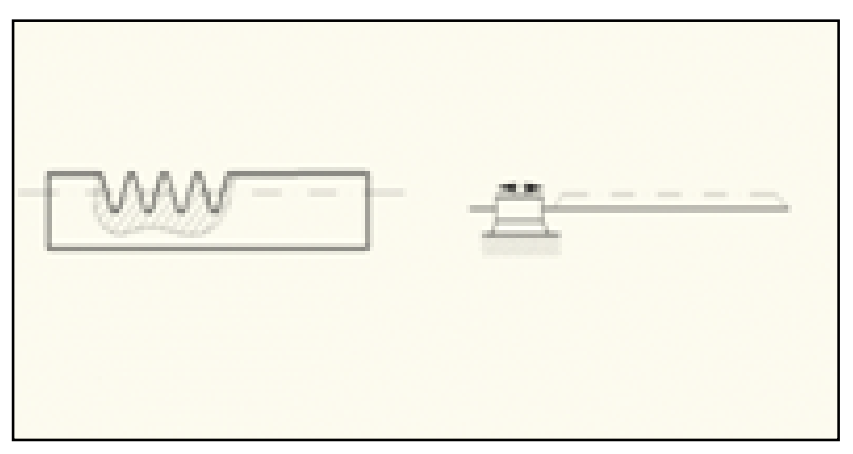

Fig. 6: Planar gear 


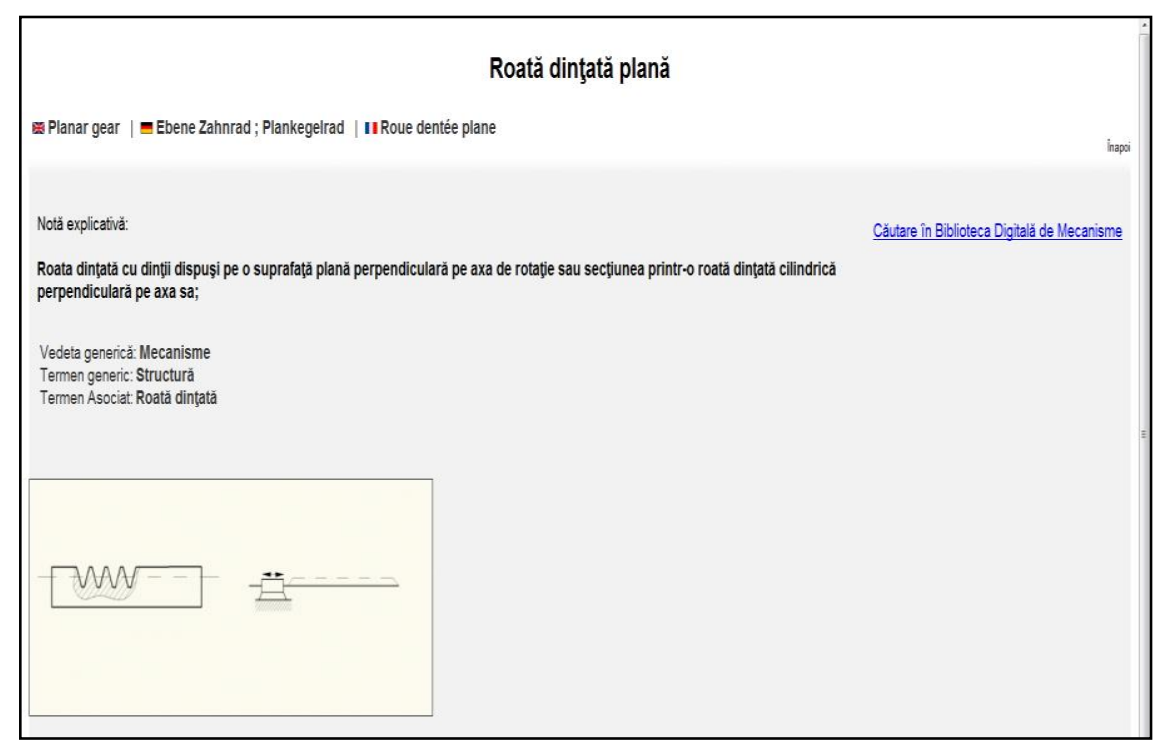

Fig. 12: Extract from the micro-thesaurus

The technical documents (also known as cognitive artefacts ${ }^{26}$ ) have a specific trajectory, directed towards a specialized professional environment, with a specialized and highly codified language; however, in order that the knowledge contained by them be included in the communication (interdisciplinary) circuit, they have to be presented in a common language, in a form easily recognizable by all types of users - for instance, the descriptors proposed above by us apply to theoreticians (specialized academics, professors, students, but also practitioners), as well as to engineers, technicians, and support personnel.

\section{Conclusions}

The rapid evolution of the socio-technical context, the rising industrialization of information, and the intensification of the usage of electronic instruments led to the diversification of the informational support, as well as the instruments of access. This implies a rise in the needed level of knowledge in order to produce, process, and disseminate information - both from the users' point of view, and from the perspective of the professionals in the information-documentation field.

Information literacy is mainly directed towards the realization of the individual's autonomy in the process of gaining a cultural or professional capital. Accepting that "the essence of a library is that it proclaims in a humble and magnificent way both its ambitions and its deficiencies," ${ }^{27}$ multilingual indexing may currently represent an efficient instrument for the promotion of linguistic and cultural diversity, for the independence of the user in finding information, especially in the context of the institutional internationalization of universities and their libraries.

\footnotetext{
${ }^{26}$ Vincent Liquète, ed. Cultures de l'information (Paris: CNRS Editions, 2014), 97.

${ }^{27}$ Alberto Manguel. Un cititor în pădurea din oglindă, 322.
} 


\section{References}

Anghelescu, Hermina. Tendințe contemporane în biblioteconomie și știința informării [Contemporary tendencies in biblioteconomy and the science of information]. Iași: Shakti, 1996.

The Association for Library Collections and Technical Services Subject Analysis Committee. Report of the Subcommittee on Semantic Interoperability to the ALCTS Subject. June 2006. http://www.ala.org/alcts/sites/ala.org.alcts/files/content/mgrps/camms/cmtes/sac/inact/semantic/sac sem rpt.pdf (accessed: 22.04.2016).

Bercovici, Sanda. Bibliotecile universitare intre tradiție și mondializare uniformizantă [University libraries between tradition and standardized globalization]. Constanța: ExPonto, 2007.

Liquète, Vincent, ed. Cultures de l'information. Paris: CNRS Editions, 2014.

IFLA. Manifestului Bibliotecilor Multiculturale [The manifesto of multicultural libraries]. http://www.ifla.org/files/assets/library-services-to-multiculturalpopulations/publications/multicultural_library_manifesto-ro.pdf (accessed: 15.04.2016).

INID. Metode de indexare in activitatea de informare și documentare [Indexing methods in the information and documentation activity]. Bucharest, 1989.

Lallich-Boidin, Geneviève and Dominique Maret. Recherche d'information et traitement de la langue. Lyon: Presses de l'ENSSIB, 2005.

Lancaster, E.W. Indexing and Abstracting in Theory and Practice. Second ed. London: Library Association Publishing, 1998.

Lovasz, E.-C. et all. "Multilingual Illustrated $\mu$-thesaurus in Mechanisms Science." In The $1^{s t}$ Workshop on Mechanisms, Transmissions and Applications, Timişoara Romania, 2011.

Lovasz, Agneta-Elisabeta. Dezvoltarea unei biblioteci digitale de mecanisme [The development of a digital library of mechanisms]. Timișoara: Editura Politehnica, 2011.

Manguel, Alberto. Un cititor în pădurea din oglindă [A reader in the forest in the mirror]. Bucharest: Nemira, 2016.

SR ISO 2788. Documentare. Reguli generale pentru elaborarea şi dezvoltarea tezaurelor monolingve [Documenting. General rules for elaborating and developing mono-lingual thesauri]. Bucharest, 2002.

Tîrziman, Elena and Maria Micle. “Adapting librarians' professional competences to current requirements through initial education and lifelong education." In European Journal of Social Sciences Education and Research 6 (2016): 161-166, http://lib.euser.org/res/jrn/ejser/jan apr 16/EJSER Volume 6 Nr 2 Jan Apr 2016.pdf (accessed: 4.05.2016).

Politehnica University Timisoara. Strategic Plan for the Internationalisation of Education 2015-2010. http://www.upt.ro/img/file/Proceduri/Strategy_for_internationalisation_UPT_2015_2020.pdf (accessed: 4.02.2016).

West University of Timisoara. Collaboration agreements with international partners. http://ri.uvt.ro/afilieri-la-asociatii-internationale_en/?lang=en (accessed: 15.04.2016). 